\section{Adres do korespondencji}

prof. WSZKiPZ dr inż. Jacek Arct Wyższa Szkoła Zawodowa Kosmetyki

i Pielęgnacji Zdrowia

ul. Podwale 13, 00-252 Warszawa

E-mail: j.arct@wszkipz.pl
Data złożenia: 5.01 .2012

Data akceptacji: 10.03 .2012

Data aktualizacji: 30.11 .2012

\title{
Education in cosmetology
}

\section{Kształcenie kosmetologiczne}

Jacek Arct

Academy of Cosmetics and Health Care, Warsaw

Estetol Med Kosmetol 2012; 2(1): 10-13

DOI: http://dx.doi.org/10.14320/EMK.2012.002

Wersja polska tego artykułu na stronie 7

Key words: cosmetology, higher education

Slowa kluczowe: kosmetologia, szkolnictwo wyższe

Development in each field of human activity is based on suitable specialist training. It applies to all areas in a modern society - production of raw materials and goods, building and maintenance of infrastructure, management, services, etc. None of these areas can function properly and develop without personnel with suitable education. At the same time, the extremely fast progress in applied sciences requires changes in the educational profile. Demand for narrow-educated specialists is decreasing and requirements for formal knowledge are frequently replaced by professional skills. The new approach to professional education is expressed in the recent amendments to the Higher Education Act. The act puts the system of the National Qualification Framework above formal specialization requirements reflected by study curricula. Taking into consideration these trends, educational strategies applied in cosmetology arouse a range of doubts. Tertiary education in cosmetology has quite a long tradition in the USA and Latin America. European institutions teaching cosmetology, located predominantly in Germany and France, provide strictly vocational training at the first level of higher education. A wide range of courses is offered, aimed at preparing different specialists, depending on the profile of an institution. Nevertheless, there is a general tendency to offer wider and wider curricula. Two main directions could be distinguished in this respect: the first prepares students for working within the beauty business, whereas the second is oriented rather towards the cosmetics industry or aesthetic medicine. The latter studies are obviously feasible only in countries with legislation allowing cosmetologists to carry out invasive treatments. The professional profiles of graduates from tertiary educational institutions significantly differ from the profile of beauticians, whose qualification allow them only to perform cosmetic treatments in beauty salons.

Cosmetology is relatively new to Poland. It was introduced into the higher education system some ten years ago, for the last three years it could be also formally continued at the second level of higher education (studies with acquisition of the Master of Science degree). In Poland, two factors have stimulates the rapid development of cosmetology studies, which are now offered by more than 60 tertiary education institutions. The first one is related to the increasing wealth of Polish society, and the resultant fashion for and expansion of beauty business. Not unimportant is the constantly growing production of cosmetics in Poland, which occupies at present the sixth position in Europe, just after Europe's five biggest economies. It seems that the second factor is sociological in nature and related to peoples' aspiration for acquiring a higher education as a means of confirming one's social position. It is manifested by a relatively large number of beauticians among cosmetology students, especially those enrolled in part-time programmes.

Such uncontrolled development and lack of contacts with more advanced foreign education institutions created the space for the misconception of a cosmetologist's 
professional profile being too often perceived as "a better trained beautician". This concept is entirely unjustified from the factual point of view. Moreover, by depreciating the profession, it has reinforced many stereotypes, and effectively obstructed the development of cosmetology as a scientific discipline. It has led to such derogative epithets for cosmetologists as "masters of patting" or "bachelors of cream mixing" frequently used in prominent scientific circles. For a full understanding of this profession, a holistic view on the so-called "beauty business" is necessary. Since cosmetology encompasses knowledge of both cosmetic products and their application (these two concepts are inseparable, and cannot exist as separate entities), a full picture of the branch appears as a very complex, multidisciplinary structure. On one hand, it is driven by developments in the basic sciences, such as skin biology, medicine, pharmacology, chemistry, physics, etc., and technologies resulting from these developments. On the other hand, this multidisciplinary structure is controlled by macro- and microeconomic factors, understood not only as profit on sales of raw materials, products and services, but also as the purchasing power of society, in which the hierarchy of needs (including those for particular types of beauty) is derived from the level of wealth and sociological mechanisms determining certain patterns (fashion) and niches in the market. Next to the direct participation in the basic tasks of the branch - manufacturing and distribution of cosmetic products, as well as implementing and maintaining services, the cosmetologist acts as a mediator between the abovementioned driving factors and executive mechanisms. This places the cosmetologists in a difficult position, often being forced to taking decisions at the boundaries of totally different areas of applied knowledge. In order to cope with these tasks, education in cosmetology should also be multidisciplinary.

It is necessary to draw a definite line between cosmetology and the topically related field of aesthetic medicine. Nonetheless, the cosmetologist and the aesthetic physician or dermatologist should co-operate, since this produces better results (also economically) than a senseless competition and mutual trespassing in fields of competence not always well-defined by the law. Such co-operation requires that both parties are adequately knowledgeable and exchange their views and opinions, a basis for which might be a co-education of interested representatives from both groups. A cosmetologist ought to understand medical treatments aimed at beauty preservation and correction of aesthetic defects, as well as be familiar with the pathology of the skin and its appendages. On the other hand, dermatologists and aesthetic physicians should know the basic rules of cosmetic treatments, and possess a certain level of knowledge about the properties of cosmetic products and their applications.
Issues related to cosmetics manufacturing, such as formulating and production, are defining a second "pole" of the cosmetologist's knowledge. This domain is a traditional field of activity for chemists, pharmacists and biotechnologists, and here it is considerably more difficult to divide the competences than at the boundaries of medicine. This is mainly due to the lack of proper legislations, but also due to a considerably wider range of topics shared by both disciplines. A certain scope of cosmetic chemistry - in particular problems related to technology, analytical chemistry, or production of raw materials, is unquestionably beyond the limits of a cosmetologist's education, who should only be acquainted with these issues to an extent allowing for communication with respective specialists. Nevertheless, there are also many issues common to both disciplines, such as properties of cosmetic forms, certain elements of cosmetic formulation, properties and activity of raw materials, problems of bioavailability of active components, methods assessing the efficacy and safety of final products, etc. In having a broader basic and specialist education, cosmetologists sometimes may have the advantage over chemists, and even pharmacists or toxicologists. Cosmetologists' knowledge on the bordering issues should allow them to communicate effectively with respective specialists.

Finally, there is the third "pole" of cosmetologists" multidisciplinary education, located at the junction between the product and the consumer, a field generally referred to as marketing, a crucial factor of the economic success and a driving force for the entire discipline. Effective marketing and advertising requires the understanding of both the needs of the target group and the advantages of a product. Only a cosmetologist is capable of delivering reliable information about a cosmetic product in a form that could be understood by marketing or advertising specialists, whether it applies to the sales of cosmetic products, or encouraging customers to buying certain cosmetic services. For only a cosmetologist knows enough of the properties of cosmetic products, cosmetic treatments and SPA services to convey the knowledge to marketing specialists in a form allowing them to undertake effective and targeted actions, create appropriate communication with customers, or explore of new niches on the market. Similar to the previously described borderline area, proper communication and mutual understanding are crucial factors. Therefore, cosmetologists ought to be familiar with marketing problems to an extent that makes such communication possible. In practice, they should possess at least basic knowledge about marketing strategies.

The above-described boundaries of disciplines are important parameters determining the scope of cosmetology education. They define the range of basic 
education - from elements of physics, chemistry and biochemistry, through basic principles of biology, anatomy and physiology, to the most important elements of medical sciences: pharmacology, toxicology, dermatology, immunology and general medicine. At the same time, a cosmetologist must also master the technical knowledge that encompasses the theory and practice of both cosmetic treatment practice and the "cosmeticology" (i.e. knowledge about the composition and activity of cosmetic products). This knowledge has to be supplemented by knowledge of the functioning of cosmetic equipment and skills in their use, as well knowledge of raw materials and formulation of cosmetic product, legal regulations, methodology of assessing the efficacy and safety of final products, knowledge about about the marketing of cosmetic raw materials, final products and cosmetic services, and finally, the skills of establishing and managing enterprises within the beauty business. It seems evident that the education covering such a broad range cannot be accomplished during relatively short, six-semester undergraduate studies in cosmetology, that rather should be focused on the basic sciences and vocational training covering the theory and practice of cosmetic treatment, as well as "cosmeticology". In order to broaden this knowledge, it is necessary to continue the education at secondary level. Therefore, graduate studies, completed with the Master's degree, should predominantly be focused on teaching interdisciplinary knowledge related to aesthetic medicine, formulation of cosmetics, assessment of final product efficacy and safety, together with some elements of the marketing of cosmetic products and services. As already mentioned, introduction of the above elements into cosmetology education is not easy, mainly due to the lack of suitable teaching staff, which is especially true with regard to "cosmeticology". It is not limited to teaching cosmetic chemistry, perceived as the knowledge on active ingredients and formulation of cosmetic products, but includes in particular teaching modern methodology of assessing the efficacy and safety of the final product. Similar problems may be encountered in the topics related to the distribution of the products - marketing techniques, psychology and advertising. Suitable teaching personnel may be recruited from two sources: the first from companies selling and distributing cosmetic products. Their employees are usually adequately trained and may also undertake teaching, especially in the light of recent amendments to the Higher Education Act, which allows the employment of professionals who do not fulfill the standard criteria for academic teachers. Quite often, however, managers of such enterprises are unwilling to share the knowledge of their employees, because the company has invested money into personnel training. This approach is unreasonable. In developed countries, corporate employees are involved in teaching, and such collaboration with educational institutions is considered as an element of corporate marketing. A second source of necessary teaching staff may be the need-centred education of present academic teachers in national as well as foreign education institutions, which may be strengthened by financial support for the participants. For example, post-graduate programmes in cosmetic chemistry are offered by the Academy of Cosmetics and Health Care in Warsaw and the Free University in Brussels.

Another factor that negatively influences the quality of teaching in tertiary education institutions (in particular those that are non-public) is the fear of discouraging some students by introducing more challenging curricula, particularly those including some elements of cosmetic chemistry. The problem has its roots in the low level of teaching in chemistry and physics in schools (a traditional weak spot of our education system). Consequently, academic education must be started from the basics in general and organic chemistry which, quite often is not well accepted by the students. Nevertheless, poorly educated graduates from secondary schools will not be prepared for following the curricula in cosmetic chemistry, biochemistry, pharmacology or skin physiology. Insufficient preparation at secondary school level hampers further education. In the end, the result is that some graduates holding a Bachelor's degree demonstrate quite an embarrassing low level of knowledge. Another source of misconceptions connected with the definition of a cosmetologist's professional profile is the lack of strict boundaries between cosmetology and aesthetic medicine. This very controversial issue leads to many conflicts and hampers co-operation between these two closely-related professional groups. Frankly, the reasons for the conflict are also rooted in the profitability of treatments under dispute. Aesthetic treatments at the boundaries of both professions, e.g. mesotherapy, tissue modeling with hyaluronic acid or polylactic acid, as well as botulin injection, are most lucrative, not only because of high margins, but also due to high demand driven by current fashion. This issue is complicated by the lack of regulations on the legal status of aesthetic medicine as a medical specialty. It is therefore necessary to impart the clear message that in principle only certified medical professionals are allowed to apply techniques connected with a direct risk to the health of a patient. These decisions should be made on the basis of factual discussion involving competent representatives of both cosmetologists and aesthetic physicians. If mutual obstinacy and short-sighted competition for direct profits should obstruct such discussion, the final decision will be made in the absence of the experts, to the detriment of both parties.

In conclusion, the future of Polish cosmetology will be shaped by both the labour market and professional 
groups. Modern markets, both in Poland and abroad, are in need of well-educated cosmetologists capable of working in all areas of the beauty business. By raising the level of education, we have the opportunity to face this demand and become a leading country in the European Union. An alternative would be the "mass production" of graduates holding Bachelor's or Master's degrees who, for the rest of their lives, could only work at treatment beds in Polish and foreign beauty parlours. The demand for such limited education seems to decrease, especially when taking into account the cost involved. It is manifested by the decreasing numbers of students undertaking extramural studies, which endangers the existence of many institutions of higher education established with much effort and at great cost. Let us remember that the long-time winners will be the tertiary education institutions whose students can easily find jobs, not only at treatment beds in beauty parlours, but also in all branches of the beauty business. Such institutions have the chance of survival in the future education market.

\section{Financing and conflict of interest}

A preliminary version of this article was published in the magazine Cosmetology Today (issue 1 of 2011). Used with the publisher's permission.

\section{Address for correspondence}

prof. WSZKiPZ dr inż. Jacek Arct, Wyższa Szkoła Zawodowa Kosmetyki

i Pielęgnacji Zdrowia

ul. Podwale 13

00-252 Warszawa

E-mail: j.arct@wszkipz.pl

Submitted: 5 January 2012

Accepted: 10 March 2012

Amended: 30 November 2012

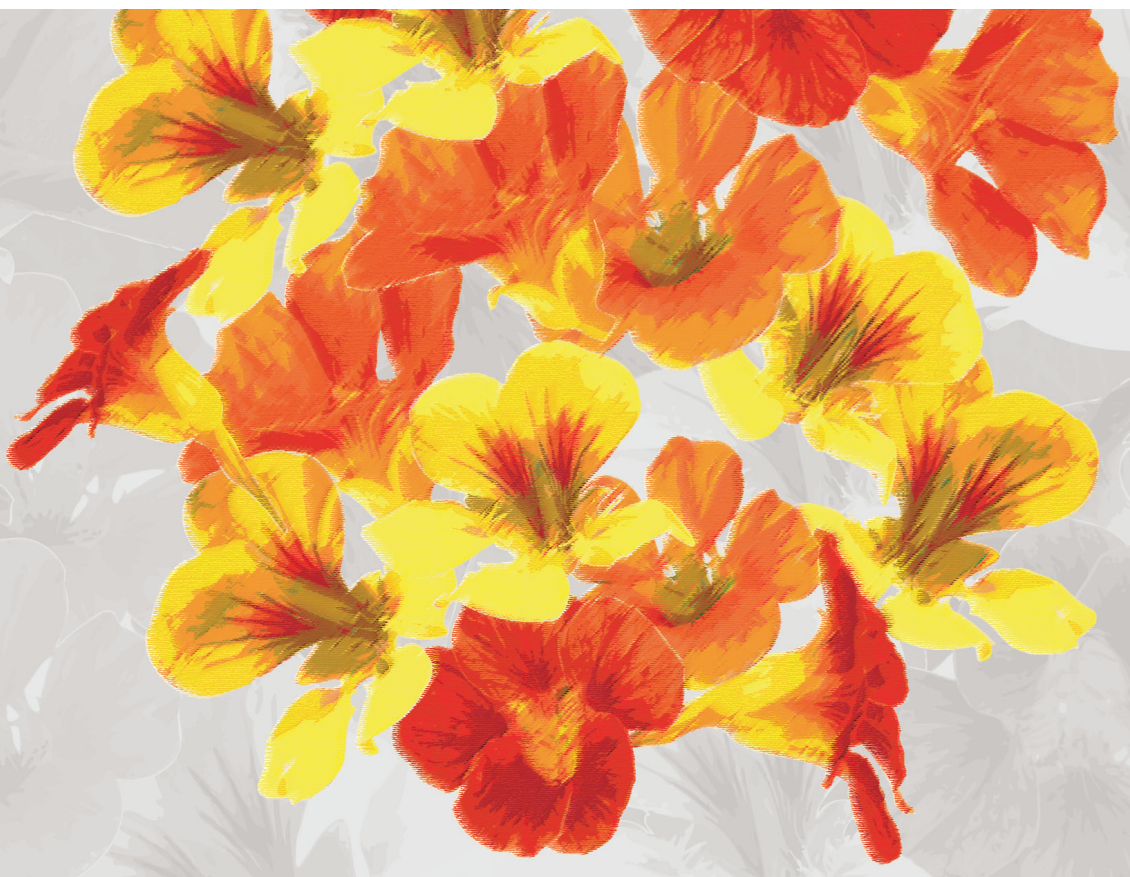

estetologia

med y c z n a kosmetologia
Pierwsze
czasopismo interdyscyplinarne z zakresu medycyny estetycznej kosmetologii i nauk pokrewnych Open Access!

zobacz na www.estetologia.pl 